\title{
The effect of mobile application programming on the educational process
}

\author{
Dawood Zahi Khutar \\ ${ }^{a}$ Al-Muthanna University, College of Engineering ,Department of Electronic and Communications \\ *dawoodzahi@mu.edu.iq:
}

\begin{abstract}
Distance learning is something really familiar nowadays. In the past few years, our world has witnessed a massive revolution in the world of information technology and provided simple ways to obtain information at reasonable prices. Today, sharing information is an integral part of every person's life. Devices such as phones, tablets, and smartphones have become the main focus of digital life. With technological progress, electronic devices go through stages of software development that allow them to perform additional, more complex tasks, and process a larger flow of information. Almost everyone between the ages of 10 and 60 owns a mobile device. So mobile apps are always up to date. Therefore, it is quite logical to use the mobile application as an auxiliary element in the educational system, especially as it provides many services such as accessing the Internet, browsing the web, sending e-mails, exchanging multimedia messages and files and providing instant messaging applications with audio and video. Focusing on employing technology in education and its curricula, regardless of its level, is considered very important. This work diagnoses what users prefer when using the e-learning application through a questionnaire distributed to a group of university students to collect data on their preferences regarding mobile applications for e-learning.
\end{abstract}

Keywords: mobile application programming, e-learning, educational process, learner, distance learning.

\section{Introduction}

The most important characteristic of the current circumstances is the rapid change and change that transcended the limits of time and space at all levels, globalization penetrated all institutions of society, and technology invaded all areas of life and its various activities. Many inventions and products that contributed to achieving human sovereignty were produced, such as Information and communication technology, multimedia, optical fibers, nuclear energy and genetic engineering. These inventions, had a great impact on entering contemporary societies into the era of the electronic revolution that appeared in the second half of the last century, and resulted in the manufacture of computers and software, which led to the development of wired communication systems[1, 2]. High-bandwidth wireless and Internet networks aim to obtain, process, store and employ information[3-5]. Which helps in the emergence of a new concept such as e-learning. The main target of this type of education is education in any place and at any time [6]. All this led to the discovery of new horizons allowing to take advantage of those crucial opportunities in education [7, 8]. The developments in the school educational reality have new tasks and responsibilities. Which made all those in charge, especially the teacher and the learner, think seriously about the importance of the new education process what it needs to be qualified and able to deal with these innovations with a high degree of proficiency and effectiveness. This is what was achieved strongly with the emergence of Mobile learning by cell phones[9-11]. The phenomenon of using the mobile phone in the educational process is a practical translation of the philosophy of distance education. The mobile-based educational process aims to expand the base of student participation in the learning process, and reducing its costs compared to traditional education systems. This philosophy affirms the students 'right to benefit from the available and unrestricted educational opportunities time, place, level or a specific type of education, not a group of students, which contributes to consolidating the concept of individual learning and democratizing education and making it more innovative[12-14]. 


\section{Previous studies}

In[15-18], authors emphasized that e-learning is one of the comfortable means of education for learners as it provides educational content in any place and time and this is not possible to fully achieve it in the traditional study style in the classroom. In[19-21], they emphasized that the learner can bypass the state of boredom in e-learning and focus on important things, unlike traditional education in the classroom where everyone is forced to focus at the same time. While it was found that e-learning is characterized by flexibility and the ability to cover its expenses in a possible way for learners through the study conducted by[22, 23]. While some authors facilitator emphasized that e-learning can be an alternative to traditional education in the event that the infrastructure and the necessary awareness are available for that[24].

\section{Methodology}

This study aims to investigate user preferences when using web and mobile applications for e-learning in higher education. The questionnaire was conducted by (234) students (a survey sample) from the students of the various Iraqi universities, which contained a set of questions related to the students' use of mobile applications and the obstacles to its use in the classroom. All these questionnaires were reviewed and studied and all the information they contained. The number of the study sample was distributed according to specialization and gender, as shown in Table (1) and Chart (1)

Table 1: Distribution of the number of the study sample according to specialization and gender

\begin{tabular}{lcccc}
\hline \multicolumn{1}{c}{ Specialization } & \multicolumn{2}{c}{ gender } & Total & percentage \\
\hline & males & female & & \\
Scientific & 67 & 62 & 129 & 55.1 \\
Humanities & 57 & 48 & 105 & 44.9 \\
Total & 124 & 110 & 234 & 100 \\
& & & & \\
\hline
\end{tabular}

Chart 1: Distribution of the number of the study sample according to specialization and gender

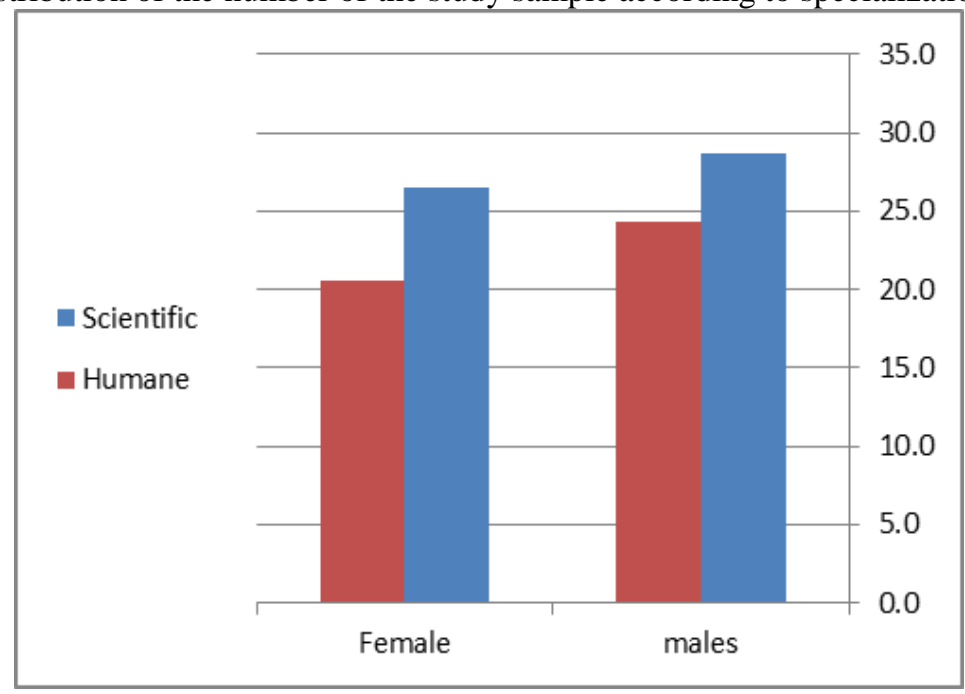

The questionnaire was based on 10 basic items that included the different uses of mobile applications, and the statistical standard for the paragraphs of the study tool was according to the five Likert scale, giving them the following grades (1 very low, 2 low, 3 mediums, 4 highs, 5 very high) and thus the degree of students' use of mobile phones applications according to the statistical standard as shown in table (2):

Table 2: The degree of students' use of mobile applications according to the five-point Likert scale $[18,20]$

\begin{tabular}{|c|c|}
\hline The percentage of the arithmetic mean & degree of use \\
\hline From 1.00 - less than 1.80 & very low \\
\hline From 1.80 - less than 2.60 & low \\
\hline From 2.60 - less than 3.40 & medium \\
\hline From 3.40 - less than 4.20 & high \\
\hline From $4.20-5.00$ & very high \\
\hline
\end{tabular}


The paragraphs included in the questionnaire were as shown in Table 3:

Table 3: The paragraphs included in the questionnaire

\begin{tabular}{|c|c|c|}
\hline $\begin{array}{l}\text { The num- } \\
\text { ber }\end{array}$ & paragraph & $\begin{array}{l}\text { Corrected correla- } \\
\text { tion coefficients for } \\
\text { the paragraph's rele- } \\
\text { vance to the measure } \\
\text { as a whole }\end{array}$ \\
\hline 1 & $\begin{array}{l}\text { I use the mobile phone to collect information related to my study through the internet and } \\
\text { store it in it. }\end{array}$ & 0.74 \\
\hline 2 & I work on my mobile phone to record some lectures with video and audio & 0.71 \\
\hline 3 & $\begin{array}{c}\text { Use a mobile phone because it is less expensive than computers and easy to use at any time } \\
\text { and place }\end{array}$ & 0.82 \\
\hline 4 & $\begin{array}{l}\text { I use the mobile phone for easy access to educational content and various libraries related } \\
\text { to my study and keep up to date on everything new }\end{array}$ & 0.77 \\
\hline 5 & $\begin{array}{l}\text { The use of mobile phones increases the effectiveness of students' participation in the edu- } \\
\text { cational process }\end{array}$ & 0.54 \\
\hline 6 & $\begin{array}{c}\text { Through the mobile phone, I follow the school announcements related to the educational } \\
\text { process }\end{array}$ & 0.72 \\
\hline 7 & $\begin{array}{l}\text { I use some computer applications through the mobile phone, such as various social media } \\
\text { sites, to exchange information with my teachers and colleagues }\end{array}$ & 0.74 \\
\hline 8 & $\begin{array}{l}\text { Handing over the homework and following it up with the teachers and obtaining the re- } \\
\text { sults through the mobile phone }\end{array}$ & 0.80 \\
\hline 9 & $\begin{array}{c}\text { The use of a mobile phone helps solve the problems of some students who are facing learn- } \\
\text { ing difficulties }\end{array}$ & 0.50 \\
\hline 10 & $\begin{array}{l}\text { Use some application programs through the mobile phone such as (language dictionaries, } \\
\text { translation, encyclopedias) and participate in educational forums }\end{array}$ & 0.66 \\
\hline
\end{tabular}

The questionnaire included the independent and dependent variables as follows:

First: the independent variables:

Gender: It has two categories: (male, female).

- Specialization: It has two categories: (Humanitarian and scientific).

Second: The dependent variable: It included the degrees of students 'use of mobile applications, represented by the arithmetic averages of the respondents of the study sample to the scale paragraphs as a whole.

To obtain the results, the following statistical treatments were used:

- $\quad$ Arithmetic means and standard deviations.

\section{Results}

In order to achieve the maximum benefit from the questionnaire to know the reality of students' use of mobile applications in the educational process in some Iraqi universities, the arithmetic averages and standard deviations of the estimates of the study sample members were calculated on each paragraph of the study tool, as shown in the following table (4):

Table 4: the arithmetic mean and standard deviations of on each paragraph

\begin{tabular}{|c|c|c|c|c|c|}
\hline $\begin{array}{l}\text { Paragraph } \\
\text { number }\end{array}$ & paragraph & $\begin{array}{l}\text { arithmetic } \\
\text { mean }\end{array}$ & $\begin{array}{l}\text { standard } \\
\text { deviation }\end{array}$ & $\begin{array}{c}\text { The } \\
\text { sequence }\end{array}$ & $\begin{array}{l}\text { degree of } \\
\text { use }\end{array}$ \\
\hline 7 & $\begin{array}{l}\text { I use some computer applications through the mobile } \\
\text { phone, such as various social media sites, to exchange in- } \\
\text { formation with my teachers and colleagues }\end{array}$ & 3.84 & 0.56 & 1 & High \\
\hline 3 & $\begin{array}{l}\text { Use a mobile phone because it is less expensive than com- } \\
\text { puters and easy to use at any time and place }\end{array}$ & 3.82 & 0.55 & 2 & High \\
\hline 1 & $\begin{array}{l}\text { I use the mobile phone to collect information related to my } \\
\text { study through the internet and store it in it. }\end{array}$ & 3.8 & 0.66 & 3 & High \\
\hline 10 & $\begin{array}{c}\text { Use some application programs through the mobile phone } \\
\text { such as (language dictionaries, translation, encyclopedias) } \\
\text { and participate in educational forums }\end{array}$ & 3.78 & 0.6 & 4 & High \\
\hline 8 & $\begin{array}{l}\text { Handing over the homework and following it up with the } \\
\text { teachers and obtaining the results through the mobile }\end{array}$ & 3.13 & 0.68 & 5 & medium \\
\hline
\end{tabular}




\begin{tabular}{|c|c|c|c|c|c|}
\hline & phone & & & & \\
\hline 6 & $\begin{array}{l}\text { Through the mobile phone, I follow the school announce- } \\
\text { ments related to the educational process }\end{array}$ & 3.11 & 0.7 & 6 & medium \\
\hline 4 & $\begin{array}{l}\text { I use the mobile phone for easy access to educational con- } \\
\text { tent and various libraries related to my study and keep up } \\
\text { to date on everything new }\end{array}$ & 3.08 & 0.64 & 7 & medium \\
\hline 2 & $\begin{array}{l}\text { I work on my mobile phone to record some lectures with } \\
\text { video and audio }\end{array}$ & 2.98 & 0.73 & 8 & medium \\
\hline 5 & $\begin{array}{l}\text { The use of mobile phones increases the effectiveness of } \\
\text { students' participation in the educational process }\end{array}$ & 2.97 & 0.71 & 9 & medium \\
\hline 9 & $\begin{array}{l}\text { The use of a mobile phone helps solve the problems of } \\
\text { some students who are facing learning difficulties }\end{array}$ & 2.93 & 0.62 & 10 & medium \\
\hline
\end{tabular}

\section{Discussion}

By following up on the results, we found that paragraph No. (7) ranked first, with an average of 3.84, which is (I use some computer applications through the mobile phone, such as various social networking sites to exchange information with my professors and colleagues). This is due to the fact that the use of social networking sites is considered It is one of the most widely used services by mobile phone users, which is characterized by being an economical and entertaining service, and an easy way to communicate between students themselves and with teachers on their cell phones anywhere and anytime, without causing any inconvenience. Also, the exchange of messages through these applications takes place between individuals, whether the phones are busy, closed or transferred, then Paragraph No. (3) came in second place, with average calculation equal 3.82, which is (Use a mobile phone because it is less expensive than computers and for ease of use at any time and place) This is due to the ease of acquisition of mobile phones by students and the ease of transporting them and using them in various times and places without causing any problem, while Paragraph No. (9) came in the last place with an arithmetic average equal 2.93, which is (the use of a mobile phone helps solve the problems of some students they face. Difficulties in learning) and preceded by Paragraph No. (5), which is (the use of a mobile phone increases the effectiveness of students' participation in the educational process). This can be explained by the fact that the activation of this type of paragraphs requires a tight environment and infrastructure, modern devices, the production of special educational software, and the design of electronic curricula. Based on educational theories pertaining to this particular type.

\section{Recommendations}

To keep up with the tremendous ascending graph in information technology, and its effect on various aspects of life, especially the educational aspect, and by looking at various studies, the researcher recommends:

- Modernizing the school curricula in line with the concepts of the information technology revolution and activating methods that achieve creativity and provide service to the individual and society.

- Emphasizing the importance of e-learning and its applicability in the educational process through mobile or integrated learning, as it combines more than one method in education, far from the boundaries of place and time restrictions, meets the requirements of the educational situation, and meets the needs of students.

- Providing the necessary infrastructure to invest in the technological revolution and spreading the necessary awareness among the user to obtain the maximum benefit from

\section{References}

[1] L. M. Abdulrahman, S. R. Zeebaree, S. F. Kak, M. A. Sadeeq, A.-Z. Adel, B. W. Salim, and K. H. Sharif, "A state of art for smart gateways issues and modification," Asian Journal of Research in Computer Science, pp. 1-13, 2021.

[2] S. Flensburg, and S. Lai, "Mapping digital communication systems: Infrastructures, markets, and policies as regulatory forces," Media, Culture \& Society, vol. 42, no. 5, pp. 692-710, 2020.

[3] M. Talaat, A. S. Alsayyari, A. Alblawi, and A. J. Hatata, "Hybrid-cloud-based data processing for power system monitoring in smart grids," Sustainable Cities and Society, vol. 55, p. 102049, 2020.

[4] N. A. Hussein. Hala A. Naman, M. Al-dabag, H. Alrikabi, "Encryption System for Hiding Information Based on Internet of Things," International Journal of Interactive Mobile Technologies (iJIM), vol. 15, no. 2, 2021.

[5] A. S. Hussein, R. S. Khairy, S. M. M. Najeeb, and H. TH., "Credit Card Fraud Detection Using Fuzzy Rough Nearest Neighbor and Sequential Minimal Optimization with Logistic Regression," International Journal of Interactive Mobile Technologies, vol. 15 , no. $5,2021$.

[6] R. N. Bolton, A. Parasuraman, A. Hoefnagels, N. Migchels, S. Kabadayi, T. Gruber, Y. K. Loureiro, and D. Solnet, "Understanding Generation Y and their use of social media: a review and research agenda," Journal of service management, 2013.

[7] F. L. Da Silva, G. Warnell, A. H. R. Costa, and P. Stone, "Agents teaching agents: a survey on inter-agent transfer learning," Autonomous Agents and Multi-Agent Systems, vol. 34, no. 1, pp. 1-17, 2020.

[8] A. Salah, R. S. Khairy, H. ALRikabi, "The Detection of Counterfeit Banknotes Using Ensemble Learning Techniques of AdaBoost and Voting," International Journal of Intelligent Engineering and Systems, vol. 14, no. 1, pp. 326-339, 2021.

[9] L. F. Jawad, B. H. Majeed, H.Salim, "Tactical Thinking and its Relationship with Solving Mathematical Problems Among Mathematics Department Students," International Journal of Emerging Technologies in Learning (iJET), vol. 16, no. 9, 2021. 
[10] D. Al-Malah, H.T. ALRikabi, "Enhancement of educational services by using the internet of things applications for talent and intelligent schools," Periodicals of Engineering and Natural Sciences (PEN), vol. 8, no. 4, pp. 2358-2366, 2020.

[11] R. Palau, M. Fuentes, J. Mogas, G. Cebrián, "Analysis of the implementation of teaching and learning processes at Catalan schools during the Covid-19 lockdown," Technology, Pedagogy and Education, pp. 1-17, 2021.

[12] N. Kolyada, L. Shapovalova, Y. Guz, and A. Melkonyan, "Distance Learning of a Foreign Language-Necessity or Future," International Journal of Emerging Technologies in Learning, vol. 16, no. 4, 2021.

[13] B. H. Majeed, L. F. Jawad, and H. Salim, "The Impact of CATs on Mathematical Thinking and Logical Thinking Among Fourth-Class Scientific Students," International Journal of Emerging Technologies in Learning (iJET), vol. 16, no. 10, 2021.

[14] G. Veletsianos, Learning online: The student experience. JHU Press, 2020.

[15] V. D. Soni, "Global Impact of E-learning during COVID 19," 2020.

[16] A. Alaidi, O. Yahya, and H. Alrikabi, "Using Modern Education Technique in Wasit University," International Journal of Interactive Mobile Technologies, vol. 14, no. 6, pp. 82-94, 2020.

[17] I. Mutambik, J. Lee, and A. J. D. E. Almuqrin, "Role of gender and social context in readiness for e-learning in Saudi high schools," vol. 41, no. 4, pp. 515-539, 2020.

[18] D. K. Abdul-Rahman, H. Salim, and H. A. Mutar, "Cloud Computing and its Impact on Online Education," IOP Conference Series: Materials Science and Engineering, vol. 1094, p. 012024, 2021.

[19] K. Kulikowski, S. Przytuła, and Ł. Sułkowski, "E-learning? Never again! On the unintended consequences of COVID-19 forced e-learning on academic teacher motivational job characteristics," Higher Education Quarterly, 2021.

[20] P. Bawa, "Learning in the age of SARS-COV-2: A quantitative study of learners' performance in the age of emergency remote teaching," Computers and Education Open, 2020.

[21] D. Z. Khutar, O. H. Yahya, and H. T. S. Alrikabi, "Design and Implementation of a Smart System for School Children Tracking," in IOP Conference Series: Materials Science and Engineering, 2021, vol. 1090, no. 1, p. 012033: IOP Publishing.

[22] S. Houlden, G.. Veletsianos, "The problem with flexible learning: Neoliberalism, freedom, and learner subjectivities," Learning, Media and Technology, pp. 1-12, 2020.

[23] D. Paulsrud and C. Nilholm, "Teaching for inclusion-a review of research on the cooperation between regular teachers and special educators in the work with students in need of special support," International Journal of Inclusive Education, pp. 1-15, 2020.

[24] H. Abbasi Kasani, G. Shams Mourkani, F. Seraji, M. Rezaeizadeh,and H. Abedi, "E-Learning Challenges in Iran: A Research Synthesis," International Review of Research in Open and Distributed Learning, vol. 21, no. 4, pp. 96-116, 2020. 